\title{
A Dialectic Model of Development of Stakeholders' Theory and Corporate Governance: from Hume Utilitarianism to Aristotelian Virtue Ethics
}

\author{
S. Morteza Ghayour B. \\ Faculty of Management \\ Imam Reza University \\ Mashhad, I.R.Iran \\ Tel: +98-912-478-0142Ｅ-mail: ghayour@imamreza.ac.ir \\ Meysam Doaei (Corresponding Author) \\ Faculty of Management and Human Resource Development \\ Universiti Teknologi Malaysia \\ Skudai, Johor Bahro, Malaysia \\ Tel: +60-10-893-1458_E-mail: dmeysam2@live.utm.my
}

Received: December 12, $2011 \quad$ Accepted: January 28, $2012 \quad$ Published: April 15, 2012

doi:10.5430/ijfr.v3n2p96

URL: http://dx.doi.org/10.5430/ijfr.v3n2p96

\begin{abstract}
Nowadays, developing the opinion of anti-corporation has formed a large part of biases and social judgments of the management science. Among these, because of performance of some companies and managers, the attention to the ethical issues in the field of theorizing and management practices has increased and has been considered by researchers in individual and organizational levels.

In this study, the authors attempt to define a general orientation of management theories by emphasizing on the two theories of agency and stakeholders in the form of offering a dialectic model of developing the Stakeholder Theory and Corporate Governance. They intend to show that despite the proposed criticisms, the organizations are moving toward developing the ethical behaviors in their series and this movement is due to the change of ethical fundamentals of corporation theory from profit-orientation of Hume to Virtue Ethics of Aristotle.
\end{abstract}

Keywords: Stakeholders' Theory, Corporate Governance, Hume Utilitarianism, Virtue Ethics

\section{Introduction}

By expanding and raising Agency Theory and increasing corporate functions and powers of the board of directors, this question was raised that how managers, who are not the owners of the firms, pursue the interest of shareholders? After the approach was changed from stakeholders' interests to social responsibilities and benefits of the society, another question was raised that whether managers' decisions will be adopted in accordance with corporate goals and demands of other multi-stakeholder partnerships and the community (Morck, 2005).

Marxist theorists believe that organizations are the powerful system which are designed to do the tasks in the best way for maximization plus profit (Morgan, 1998).

Marxist scholarship is partisan; it is constantly seeking to highlight the problems of organizations and to show why these problems cannot be satisfactorily resolved without fundamental change in social structure (Adler, 2011). In addition, the theories of some scholars' such as Marcuse, Habermas, Goldner, Dahrendorf, Silverman, Lyotard, Jones, Roszak, and Reich express that the emergence of anti-corporate ideas based on specific philosophical assumptions, which declared that an organization is an immoral and inhuman phenomenon (Burrell \& Morgan, 1979). Anti-corporate ideas emphasize on concepts such as alienation, domination, control, one-dimensional society and capitalist development as the dark dimension of dominated organizations (Burrell \& Morgan, 1979).

Corporate governance is a set of interior and exterior control mechanisms of the firm which appropriate the balance between equity in one hand and the authorities of director on the other hand. Finally, these mechanisms provide a 
reasonable assurance for shareholders and other stakeholders with regard to maintaining ethical, social and corporate interests (McGee, 2008).

The establishment of appropriate corporate governance mechanisms is the essential action for optimal use of resources, promoting accountability, transparency, fairness and rights of all stakeholders (Mackenzie, 2007).

This study examines a few topics related to Corporate Governance. First of all, the concept of corporate governance, its mechanisms and theoretical background are expressed. Secondly, ethical approaches influencing on the process of a dialectic model of development of stakeholders' theory and corporate governance are discussed. Finally, the model is presented.

\section{Corporate Governance}

At first it is considered necessary to refer to the background of corporate governance for a comprehensive definition. Corporate Governance comes from Latin the word "Gubenare", which means leading, and it was used for leading a ship as the first definition of corporate governance focused on leading rather than control (Cascarino, 2007).

Mathiesen (2002) defined Corporate Governance as the scope of economy which its task is to consider how to motivate the manager with compensation mechanisms such as contracts, corporate plan and setting some rules to attempt for improving performance and to achieve competitive return.

In most definitions, a kind of ethical approach and comprehensive definition of corporate governance is regarded to understand how to achieve such an understanding of the subject areas that requires ethical change in the approach of corporate theory.

Parkinson (2006) has developed two perceptions of corporate governance. Firstly, he maintained that corporate governance refers to some methods according which the society attempts to act for the interests of the Firm through the public profit, therefore, the firm is managed by the external factors. The second conclusion is related to the design of answering system in the structures and the process of the firm. This makes us sure that the firm managers manage it according to the legal (specified) purposes of the business.

\section{The Purpose of Corporate Governance}

Corporate Governance simplifies the effective management and control in businesses. So, firms can provide an optimum efficiency for stakeholders. The aims of Corporate Governance are summarized as below (Narayan 2003):

To increase shareholders' values

To consider the interests of shareholders, customers, employees and the general public

To ensure transparency and integrity in the exchange of information and access to complete, accurate and transparent information for all stakeholders

To ensure accountability of performance

To conduct the firm to the highest operating and behavioral standards

Corporate Governance includes the mechanisms between various actors (stakeholders) and the targets on which basis, the firm is managed. In this mechanism, considering the community is very important. In this context, the primary bases of Corporate Governance consist of: equality, transparency and accountability (Valor, 2005).

One of the most important responsibilities of managers in Corporate Governance is to promote a public opinion regarding accountability of the organization performance. The response time of admission requires moral and ethical consequences that follow (Zimmerli, Richter, \& Holzinger, 2007).

\section{Research in the Areas of Corporate Governance}

Researches and studies related to Corporate Governance include the relationships between Corporate Governance mechanisms with a variety of outcomes (Banchuenvijit, 2007; Bushman \& Smith, 2001; D'Souza, Megginson, \& Nash, 2007; Imhoff, 2003). In general, we can describe the results and consequences in two areas of financial and non financial performances. The area of financial performance is related to financial results such as quality of financial reporting and accounting, information disclosure, investment decisions, corporate risk, increase firm value, growth, stock price and financial resource allocation (Banchuenvijit, 2007; Imhoff, 2003).

The second area of corporate governance is related to outcomes of non-financial performance (Heath \& Norman, 2004; Marnet, 2008; Phillips, 2003; Trailer, Rechner, \& Hill, 2004; Valor, 2005). One of the similar parts in the researches is the direct and implicit attention to the moral results which are based on the performance of the corporate mechanisms. The explanation of change in the ethical principles of the business theories is followed in this paper to achieve the mechanism of the Corporate Governance regarding the ethical approaches in the west. Theories about the formation of 
the agency and stakeholders and provision a Corporate Governance mechanism can be followed (Wearing \& Wearing, 2005).

\section{Agency Theory}

Agency Theory is stated in various texts, including economics, insurance, management and accounting. This theory is related to a situation when a person transfers the responsibility of making decision about distribution of financial and economic resources or performing a specific service during the contract to someone else. The first person is called "the owner", and the second person is called "the representative" (Brown Johnson \& Droege, 2004).

The separation of ownership and management is an issue which is introduced from the early twentieth century in the literature of the management and organization theory. When the top managers were not able to run all the activities and assigned it to the professional managers., this event created some uncertainty for the owners, and they knew it as a right for them to control and monitor the managers of modern firms (Fama \& Jensen, 1983).

Some authors believe that the Agency Theory originates from Adam Smith's book "Wealth of Nations" in 1776. Adam Smith states that the managers do not care about their employees as much as their financial recourses (Heath \& Norman, 2004).

To prevent this problem, the firm becomes a set of contracts and the relationships among people in Agency Theory that the most important one is the agency relationship (Donaldson \& Preston, 1995).

The agency relationship indicates that one part such as employer, owner or private capital with significant responsibility, delegates the work to other reference work as agent. Of course the agent does the work on behalf of the employer. Agency Theory explains the relationship between employers and brokers using the metaphor of agency contract (Governance, 2004).

Agency Theory is trying to solve two problems. The first problem appears when the managers' desires and goals contrast with their employers' desires or when it becomes costly for the managers to find out if their employers exactly do whatever they want. The second problem is the problem of dividing the risk, and it happens when the boss and his agent disagree with each other. The problem comes because it is possible that the boss and his agent want different actions because of the willingness to take risks in different ways (Rahman Seresht, 2007).

Non-ethical problems such as accounts, fraud, deceit and lack of transparency which occurred in some firms like The Ron, Word palate, Maxwell, Shell, caused that the critics of Representation Theory know it as mundane, inhumane and even dangerous.

\section{Stakeholder Theory}

Some authors argue that Agency Theory focuses solely on shareholders' interests, and the managers will be under observation of shareholders who just care about short-term interest and are not interested in long-term plans and profit. In other words, following short-term profits costs lack of enough attention to the long-term performance (Trailer, et al., 2004).

One of the solutions of this problem is to focus on institutional shareholders. The most fundamental point is that something which is always desirable for the shareholders is not desirable for the community. So, the firm policies which have the most value for the shareholders may not have maximum value creation for the whole community. However, the life and continuing the firm's activities depends on gaining legitimacy by the society and the environment (Phillips, 2003). This subject changed the attention to stakeholders and the formation of stakeholders' theory, which was in contrast with the Agency Theory. Agency Theory stated that the main default in the creation of corporate strategy should maximize the profit of shareholders while the Stakeholder Theory emphasizes on all people who directly or indirectly are in contact with the activities of the firm, outcomes and its results (Wearing \& Wearing, 2005).

The basis of Stakeholders' Theory is that the effect of firms on the community is really deep, so, except shareholders, more parts of the community should be under attention and should be responded. Although this reaction was a moral choice or a moral pressure in relation to the firms, stakeholders not only affected by firms but also affect on them (Klein \& Harford, 2004). In this theory, stakeholders include shareholders, employees, vendors, customers, creditors, similar firms, competitors, government and general public. Enrollment range of stakeholders reaches to a place that the future generations and animal species are considered, too. Kaptein (2004) believes that corporate governance framework as a coherent system that includes professional and ethical principles can ensure the life of the organization through paying attention to other stakeholders. 


\section{Ethical Reflection}

The term moral includes the principles and reasoning processes in order to discover what is true or false or what is better or worse than anything else. Richard L. Daft regards moral as some values which control the individual or collective behavior as right or wrong. Morality in the management discusses dos and don't of managers' decisions or practices and encourages them to make logical and good decisions and prevents them from making irrational, evil and ugly decisions (Daft, 2009).

Reflection of morality in the society is in the form of social responsibility and commitment towards the society, which had been missed in the Agency Theory. Dubrin et al. (1996) state that the managers must be responsible for some problems such as environmental pollution, discrimination, poverty, unemployment, and inflation in their decisions. Therefore, they should not consider just their shareholders' profits. The organization as a subsystem in the society is responsible for the effect of its performance on the society and people. In Stakeholder Theory, managers should not only provide profit and interest for their organizations, but they also should participate in the process of providing and satisfying welfare, comfort, needs and interests of the society (Durbin, et al., 1996).

\section{The Ethic Fundamental of Corporate Theory and Conventional Rationality of Organization}

Classical types of organizations that are managed in different ways such as the royal office and the traditional, authoritarian rule of the rich, democracy, etc., have been created and function based on a common logic. The logic of such organization is that the owners are looking for more values, and the organization is a tool for earning more money (Pfeffer, 2004).

In owners' or shareholders' decisions, a kind of selfishness and disregard is seen toward for others in firms, that is the common logic in the establishment of the firms and investment in them. The Agency Theory is looking for a way to achieve the maximum efficiency, choosing the best way of using the capitals and the minimum cost of transactions based on this logic and through a contract-oriented approach (Kocherkevych Zaiats, 2008).

Jensen and Meckling (1976) believe that decreasing the cost of transactions will be specifically possible by agency relations. When the agency theory is in the direction of the common logic of the firm, the investors profit is created.

The corporate classic theory and the business are based on the following defaults (Arthurs \& Busenitz, 2003):

Shareholders are the owners of the firm.

Stakeholders want to maximize their profit.

A collection of relations form the firm.

The goal of the firm is to maximize the value of stakeholders' assesses.

The result of classical theory and its logic lead to moral slips in agency relationships. Problems such as failure to complete the perpetrators, preference of their individual interests, diverging interests of the community, deceitful reports, lack of trust, etc. are examples of unethical behavior, which changed the path of hypothesize to the agency theory and corporate governance. One reason of non-ethical behavior in the organization is that a few of people in the firm have the most power and resources. So, it causes non-ethical behaviors (Pfeffer, 2004).

Corporate Governance is a reaction to the subject of agency which is caused by "separation of management control from ownership". Before 1970 that Jensen represented the Agency Theory, Conflict and Interest, there had been less attention to other stakeholders and corporate governance. After the representation of Agency Theory, the relations of agency affected the different issues in financial, economic and managerial literature excessively, gradually with the emergence of professional ethic scandals, corruption and bankruptcy of financial firms, the idea of corporate governance system was considered (Anderson, Melanson, \& Maly, 2007).

In Corporate Governance, a framework is created and strengthened for an effective, efficient and correct conduct, management of businesses, support of rights and profits of all investors, and stakeholders and decreases of the contrast between managers and stakeholders. Corporate Governance not only represents a legal and regular framework to determine the relationships and responsibilities among shareholders, board members, top manager and other stakeholders, but also tries to provide the insurance of competitive performance, which is needed for the health and safety of activities, to make sure about stakeholder's' rights and provide criteria and mechanisms to monitor and control the activities of managers and oblige them for responding (Deckop, Merriman, \& Gupta, 2006).

The main objectives of Corporate Governance are accountability, transparency, justice, fairness and respect to the stakeholders' rights and the public interests. It is one of the basic principles of corporate governance to ensure considering ethics and other values which state the changes in ethical fundamentals of Corporate Theory. The fundamental issue in designing Corporate Governance principles is that the principles of Corporate Governance can be considered the interests of all stakeholders in the organization. Pursuing the interests of all stakeholders is done in the all 
activities of managers from decisions to work. Corporate Governance makes the conditions unsafe for the occurrence of fraud, account planning, deception, negligence in the reflection reality, business reputation, and lack of transparency (Marnet, 2008).

Actually, the Corporate Governance is a frame in which the firm converts to moral and it provides a framework for making ethical decisions. Organizational ethics of Corporate Governance, with emphasis on transparency, clarifying anti-morality, and taking responsibility, makes it necessary to develop comprehensive and ethical codes in the organization including the list of requirements and ethical obligations that are designed in the form of Dos and Don'ts (Mackenzie, 2007).

Corporate Governance increases the ethical decision-making in organizations and raises their responsibility toward stakeholders. Moral decisions and ethical values are shown in some items such as conflict of interest, corporate opportunity, fair trading, trust, proper use of firm assets, taking action according to the rules and regulations and encouraging the prevention from immoral activities (Simon, 2003).

Rakoff (Breeden, 2003) provides seventy-eight recommendations in connection to different mechanisms and issues of Corporate Governance such as the number of board members and their composition, the requirements of their independence, social responsibility, their training, managing directors, corporate leaders, non-executive directors, audit committees, risk management, ethics offices, programs of a moral and ethical charter. Considering these mechanisms and issues, it is possible to return trust to the firms and businesses.

\section{Pass from Hume Utilitarianism to Aristotelian Virtue Ethics}

Sison and Pfeffer (2010) point to some examples of organizations which provide a condition for non-ethical behaviors individually or in the organization considering the classical and common logic of formation of firms. They state that when the organizations establish based on the common logic, they arrange their activities based on profit-oriented ethics and because of considering the shareholders profits and interests as the main goal, non-ethical and non-professional behaviors occur in the organization by individuals. These behaviors continue to expand the logic of firms' formation and cover beyond their owners' concepts. These changes and movements from Agency Theory to Stakeholders' Theory and Corporate Governance cause some changes in ethical principles.

In the classical theory of management, affected by changes in relationships between human and the world, morality found different meaning and human's profit was considered as the main goal. This can be seen in Hume, Niche and Mil's approach (MacIntyre, 1981). MacIntyre (1981) realizes that the only way to save the West is to return to the tradition of Aristotle's Ethics and believes that the practical and theoretical ethics in the west result from individualistic liberalism and modernism.

This, of course does not mean that the classical theories lack a moral basis, but it means that the main logic has been based on a profit-oriented conception which has existed in Hume thought and the shareholders have been in the focus of attention in classical theories, especially in Agency Theory -, as a character (Pfeffer, 2004).

Aristotle's belief of Virtue Theory and Hume's orientation to profitability have been two basic defaults of the new and old theories about the organization. Profit orientation and virtue ethics as two types extremist theory together with Kant's theory of task orientation are known as moral theories in the West (Shariyari, 2005). Aristotle's ethics is one of the main elements of his philosophy due to the nature and purpose and it is assumed as an invitation to the intellectual virtues such as wisdom, temperance and justice of the West that has attracted the managers' and experts' attention to the discussion of organizational ethics, and has coordinated the organizational behavior regarding social values (Irwin, 1999). This approach is looking for a change in topic value through which issues such as, lack of clarity, deception, lying, etc. which challenge the organization are condemned (Sison \& Pfeffer, 2010).

If we accept the management functions are related to the true meaning of responsibility and taking the responsibility and if we know the responsibility as a result of respecting to the ethical principles, we will find out that ethics must be created and supported according to a rational and logical plan (Bishop, Connors, \& Sampford, 2003).

Unlike the profit orientation, Aristotelian Ethical Theory is a theory which realizes the ethical virtues as the basis for right and wrong actions and tries to encourage people to have ethical virtues instead of focusing on external behavior. In Aristotle's view, human's actions should be beneficial both for him and for others, and this is the virtue. Virtue is something superior and better than a computing-oriented logic in Aristotle's Theory (Irwin, 1999).

Justice is one of the most significant virtues in Aristotle's view. Even it can be considered as the most important part of Aristotle's Ethics. In Aristotle's view social justice is prior to individual justice and in general, justice is used for anything that requires the law. In other words, Aristotle believes that justice means following and obeying the rules (Maclntyre, 1988). 
Anderson (1984) believes that a decision is ethical when it includes three elements: first, the behavior of the person who makes the decision based on personal characteristics, personality, values, education and motivation. The second is social norms according which the person will coordinate his/her own decisions with acceptable standards in a society or culture. The third is that the ethical decisions are made when the behavior of a person is observed and interpreted.

The observations show that there is no change for the individuals under the condition of Anderson's model, but just the organizations have to respect to ethical principles because of magnifying the role of social norms and paying attention to other individuals' understandings (O'Donoghue \& Rabin, 2006).

Another distinction of ethics in Stakeholder's Theory and Corporate Governance is pluralism in them. The distinction of pluralism' belief is its tendency to identify the loss and to prevent from it, which may be imposed on the society by the firms. Pluralists emphasize justice and cooperation and look for an authentic community in which providing the requirements of the community justifies the activities of the firm. While the pluralists emphasize managers' social responsibilities, contract-oriented people are looking for a freedom in two parts of the contract's actions. Pluralists believe that continuity of contract-oriented approach causes exploitation and alienation among people. Organizational life in contract-oriented realizes the increasing of the value of shareholders' wealth as the role of the manager. In pluralism's belief the managers are not only responsible for shareholders' interest, but they also have the social responsibility towards all stakeholders in the firm and providing the real needs for them. Maximizing the efficiency and output of shareholders may disturb the order of the society and decrease the trust of community. On the other hand, the patterns of Corporate Governance are provided by emphasizing on individual, group and other cultural values in the society (Licht, 2002).

Beside the changes in ethical principles, what that can be generally noted as effective factors on the Agency Theory in a dialectical process of creating Stakeholders Theory and Corporate Governance are separation of ownership from management, and changes in regulatory environment, in the nature of function and in the organizational structure (Bradley, Schipani, Sundaram, \& Walsh, 1999).

Macleod (2006) and his colleagues assume the realization of justice based on four factors: regional and international organizations, corporate governance, civil society and human rights. He believes that Corporate Governance adjusts the behavior of business according to regulations and ethical principles. It is because of some obligations such as transparency of information, information asymmetry, and responding, along with environmental regulations that determine the ethical behaviors in the organization. This ethical behavior results in justice.

Considering the theoretical change in the firm, Aristotelian virtue ethics, pluralism approach, models of ethical decision-making and the factors of justice in Macleod's view, represented in this study, the conceptual model as "the dialectical development of Stakeholder Theory and Corporate Governance" can be represented as Figure 1.

Dialectical character of this model means that throughout the firm's theory development including from Agency Theory to the Theory of Corporate Stakeholders, corporate governance requirements, behaviors and the unethical consequences impose some damages on the firm and the community. To prevent similar events that had happened, the theorizing and management practices changed according to the principles of ethical behavior. Individual-oriented in the characteristic of the firm has been replaced by pluralism. And norms and requirements of the society have also been considered.

\section{Conclusion}

This research has concluded that by changing the focus of studied theories, the ethics principles of these theories have been changed from Hume's profit-oriented to the social responsibilities and Aristotle ethical virtues. Apart from mandatory, voluntary, conscious and unconscious aspects, this change has had specific consequences, that we can mention the promotion of ethical behaviors as one of them. In other words, the modern world in general and the organizations, in particular, in contrast with two prominent ethical approaches in the West, has chosen the Aristotle's approach and this decision is an initiator of the ethical implications in two areas of theorizing and actions of management.

\section{Acknowledgements}

The authors would like to thank the editor and anonymous reviewers for their suggestions for improving the paper. In addition, they are grateful to Imam Reza University for providing full support to this research.

\section{References}

Adler, P. S. (2011). Marxist philosophy and organization studies: Marxist contributions to the understanding of some important organizational forms. Philosophy and Organization Theory (Research in the Sociology of Organizations, Volume 32), Emerald Group Publishing Limited, 32, 123-153. 
Anderson, D. W., Melanson, S. J., \& Maly, J. (2007). The Evolution of Corporate Governance: power redistribution brings boards to life. Corporate Governance: An International Review, 15(5), 780-797. http://dx.doi.org/10.1111/j.1467-8683.2007.00608.x

Arthurs, J. D., \& Busenitz, L. W. (2003). The boundaries and limitations of agency theory and stewardship theory in the venture capitalist/entrepreneur relationship*. Entrepreneurship Theory and Practice, 28(2), 145-162. http://dx.doi.org/10.1046/j.1540-6520.2003.00036.x

Banchuenvijit, W. (2007). Three essays on privatization and corporate governance. Southern Illinois University at Carbondale.

Bishop, P., Connors, C., \& Sampford, C. J. G. (2003). Management, organisation, and ethics in the public sector: Ashgate Pub Ltd.

Bradley, M., Schipani, C. A., Sundaram, A. K., \& Walsh, J. P. (1999). Purposes and Accountability of the Corporation in Contemporary Society: Corporate Governance at a Crossroads, The. Law and Contemp. Probs., 62, 9. http://dx.doi.org/10.2307/1192226

Breeden, R. C. (2003). Restoring Trust: Report to The Hon. Jed S. Rakoff, The United States District Court for the Southern District of New York, on Corporate Governance for the Future of MCI, Inc. Corporate Monitor, 44.

Brown Johnson, N., \& Droege, S. (2004). Reflections on the generalization of agency theory: Cross-cultural considerations. Human Resource Management Review, 14(3), 325-335. http://dx.doi.org/10.1016/j.hrmr.2004.06.003

Burrell, G., \& Morgan, G. (1979). Sociological Paradigms and Organizational Analysis: Ashgate Publishing.

Bushman, R. M., \& Smith, A. J. (2001). Financial accounting information and corporate governance* 1. Journal of Accounting and Economics, 32(1-3), 237-333. http://dx.doi.org/10.1016/S0165-4101(01)00027-1

Cascarino, R. E. (2007). Auditor's guide to information systems auditing: Wiley.

D'Souza, J., Megginson, W., \& Nash, R. (2007). The effects of changes in corporate governance and restructurings on operating performance: Evidence from privatizations. Global Finance Journal, 18(2), 157-184. http://dx.doi.org/10.1016/j.gfj.2006.04.004

Daft, R. L. (2009). Organization theory and design: South-Western Pub.

Deckop, J. R., Merriman, K. K., \& Gupta, S. (2006). The effects of CEO pay structure on corporate social performance. Journal of Management, 32(3), 329. http://dx.doi.org/10.1177/0149206305280113

Donaldson, T., \& Preston, L. E. (1995). The stakeholder theory of the corporation: Concepts, evidence, and implications. Academy of management Review, 65-91.

Durbin, A. J., Ireland, R. D., \& Williams, J. C. (1996). Management and organization: South-Western, West Texas.

Fama, E. F., \& Jensen, M. C. (1983). Separation of ownership and control. JL \& Econ., 26, 301. http://dx.doi.org/10.1086/467037

Governance, D. S. G. o. C. (2004). OECD principles of corporate governance: Publications de l'OCDE.

Heath, J., \& Norman, W. (2004). Stakeholder theory, corporate governance and public management: what can the history of state-run enterprises teach us in the post-Enron era? Journal of Business Ethics, 53(3), 247-265. http://dx.doi.org/10.1023/B:BUSI.0000039418.75103.ed

Imhoff, E. (2003). Accounting quality, auditing and corporate governance.

Irwin, T. (1999). Aristotle: Nicomachean Ethics. Indianapolis, IN: Hackett.

Jensen, M. C., \& Meckling, W. H. (1976). Theory of the firm: Managerial behavior, agency costs and ownership structure. Journal of financial economics, 3(4), 305-360. http://dx.doi.org/10.1016/0304-405X(76)90026-X

Kaptein, M. (2004). Business codes of multinational firms: what do they say? Journal of Business Ethics, 50(1), 13-31. http://dx.doi.org/10.1023/B:BUSI.0000021051.53460.da

Klein, M., \& Harford, T. (2004). The Global Challenge of Corporate Governance. Financial Times.

Kocherkevych Zaiats, N. (2008). Essays on corporate governance, agency conflicts, and regulations. The University of Wisconsin-Milwaukee. 
Licht, A. N. (2002). Accountability and Corporate Governance. September). Available at http://ssrn. com/abstract, 328401 .

MacIntyre, A. C. (1981). After virtue: A study in moral theory: University of Notre Dame Press (Notre Dame, Ind.).

Mackenzie, C. (2007). Boards, Incentives and Corporate Social Responsibility: the case for a change of emphasis. Corporate Governance: An Review, 15(5), 935-943. http://dx.doi.org/10.1111/j.1467-8683.2007.00623.x

Maclntyre, A. (1988). Whose justice? Which rationality. London: Duckworth, 12, 252.

Marnet, O. (2008). Behaviour and rationality in corporate governance. International Journal of Behavioural Accounting and Finance, 1(1), 4-22. http://dx.doi.org/10.1504/IJBAF.2008.021027

Mathiesen, H. (2002). Managerial ownership and financial performance: Copenhagen Business SchoolCopenhagen Business School, Institut for International Økonomi og VirksomhedsledelseDepartment of International Economics and Management.

McGee, R. W. (2008). Corporate governance in developing economies: country studies of africa, asia and latin america: Springer Verlag.

Morck, R. (2005). A history of corporate governance around the world: family business groups to professional managers: University of Chicago Press.

Morgan, G. (1998). Images of organization: Berrett-Koehler Publishers.

O’Donoghue, T., \& Rabin, M. (2006). Incentives and Self Control. Levine's Bibliography.

Parkinson, J. (2006). Corporate Governance and the Regulation of Business Behaviour. Global Governance and the Quest for Justice, 2.

Pfeffer, J. (2004). HOW ECONOMIC LANGUAGE AND ASSUMPTIONS UNDERMINE ETHICS: REDISCOVERING HUMAN VALUES. Tecnun Journal.

Phillips, R. (2003). Stakeholder theory and organizational ethics: Berrett-Koehler Publishers.

Rahman Seresht, H. (2007). Theories of organization: from modernism to post-modernism. Tehran: Doran.

Shariyari, H. (2005). Moral Philosophy in thought Western, MacIntyre Attitude: SAMT.

Sison, A. G., \& Pfeffer, J. (2010). Corporate governance and ethics: an Aristotelian perspective: Edward Elgar Publishing.

Trailer, J., Rechner, P., \& Hill, R. (2004). A compound agency problem: an empirical examination of public-private partnerships. Journal of American Academy of Business, Cambridge, 5(1/2), 308-315.

Valor, C. (2005). Corporate social responsibility and corporate citizenship: Towards corporate accountability. Business and Society Review, 110(2), 191-212. http://dx.doi.org/10.1111/j.0045-3609.2005.00011.x

Wearing, B., \& Wearing, R. (2005). Cases in corporate governance: Sage Publications Ltd.

Zimmerli, W. C., Richter, K., \& Holzinger, M. (2007). Corporate ethics and corporate governance: Springer Verlag. http://dx.doi.org/10.1007/978-3-540-70818-6 


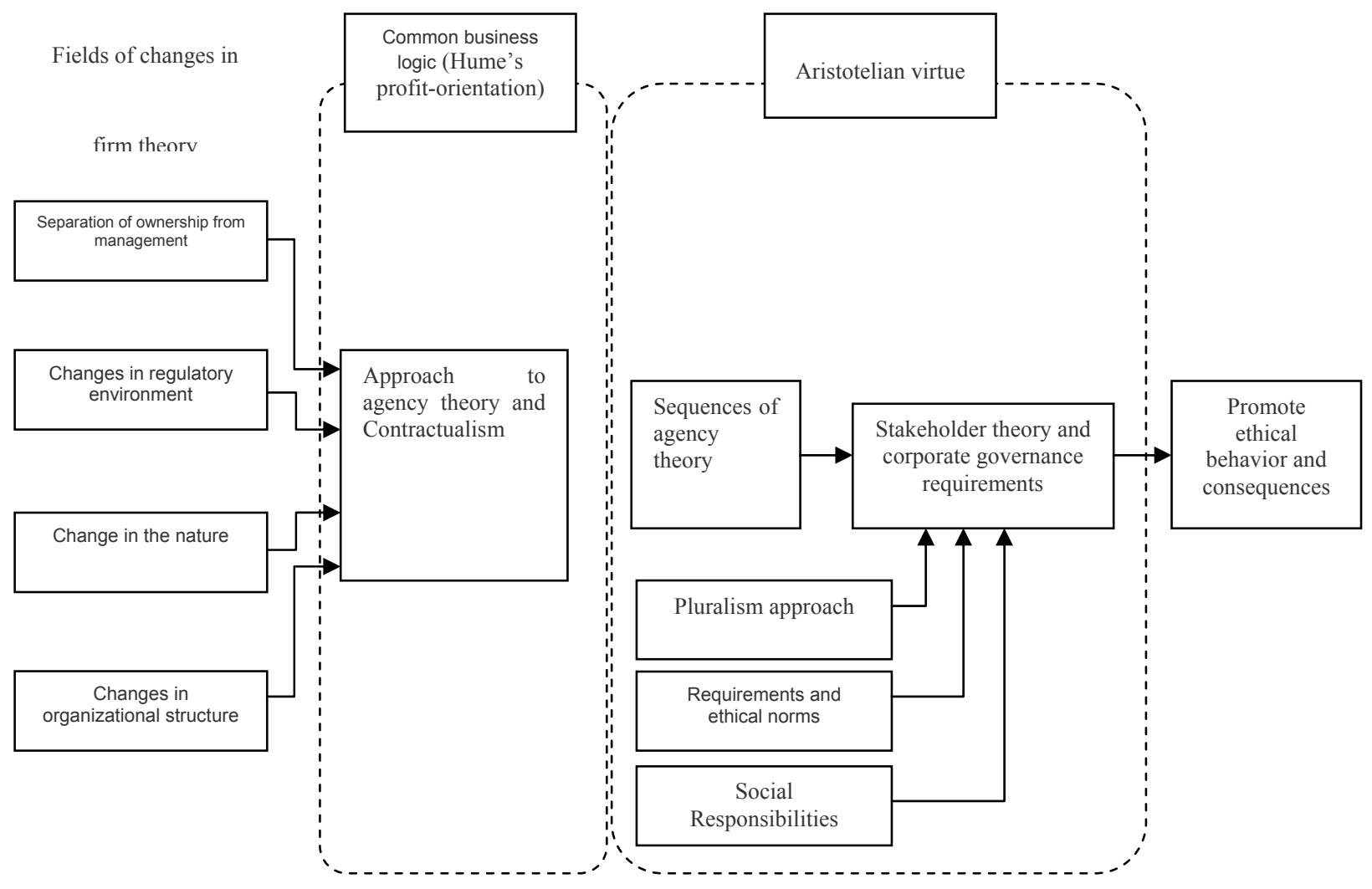

Figure 1. Dialectical Model of Stakeholder Theory and Corporate Governance 